\title{
NEO-KOLONYALİST AÇIDAN AFRİKA SİNEMASINA BAKMAK
}

\author{
Selim Beyazyüz*-Meral Serarslan**
}

\section{ÖZET}

19. Yüzyıl'da Avrupa teknik, teknolojik ve ekonomik alanlarda gösterdiği hızl ilerleme ve Endüstri Devrimi'nin etkisiyle dünyanın lideri konumuna gelmiştir. Batı ülkelerinin Endüstri Devrimi ile ortaya çıkan hammadde ve iş gücü gereksinimi ise sömürge ülkelerden să̆lanmıştır. İkinci Dünya Savaşı sonucunda dünyadaki güç dengelerinin değişmesi Avrupa ülkelerinin güç kaybetmelerine neden olmuş, sömürgeleştirdikleri ülkeleri ellerinde tutamaz hale gelmişlerdir.

İkinci Dünya Savaşı sonrasında dünyada ortaya çıkan iki süper güç ABD ve SSCB kendi sistemlerinin dünyaya egemen olması için çabalamışlardır. Bu tablonun dışında kalan ve henüz gelişme aşamasında olan ülkeler Üçüncü Dünya Ülkeleri olarak adlandırılmışlardır. $A B D$ ve SSCB'nin önerdiğ i kodlar dışında yeni ve farklı bir yaklaşım geliştirmeye çalışan Üçüncü Dünya Ülkeleri, siyaset zeminindeki gelişmelere paralel olarak sanatsal anlamda da faaliyetler göstermişlerdir.

Bu çalışmada, İkinci Dünya Savaşı sonrasında dekolonizasyon süreci ile birlikte bağımsızlığını kazanan Üçüncü Dünya Ülkeleri'nin geliştirdikleri sinema dili, yönetmenliğini Ousmane Sembene'nin yaptı̆̆g Xala filmi özelinde ele alınmıştır. Xala'nın Birinci, İkinci ve Üçüncü sinema bağlamındaki yerini saptamayı amaçlayan bu çalışmada nitel metin çözümlemelerinden biri olan tarihsel film eleştirisi kullanılmıştır. Xala'nın, İkinci sinemanın olanaklarının bir kısmını kullanarak, Üçüncü sinema anlatısı olmaya aday bir film olduğu sonucuna ulaşılmıştır.

Anahtar Kelimeler: Batı, sömürgecilik, İkinci Dünya Savaşı, Üçüncü Sinema.

\footnotetext{
* Arş. Gör., Selçuk Üniversitesi İletişim Fakültesi,ORCID ID: 0000-0002-8384-8992

** Prof. Dr., Selçuk Üniversitesi İletişim Fakültesi, ORCID ID: 0000-0003-2059-5585

Makale Gönderim Tarihi: 08.03.2019- Makale Kabul Tarihi: 08.05.2019
} 


\title{
LOOKING ON THE AFRICA CINEMA IN THE NEO-COLONIALIST CONTEXT
}

\begin{abstract}
The rapid progress of Europe in technical, technological and economic fields in the 19th century and the important discoveries that emerged under the influence of the Industrial Revolution led the Western world to become the leader of the world. Necessary raw material needs and labor requirements emerged along with the Industrial Revolution of the Western countries and these requirements were obtained from the colonial countries. The change of power balances in the world at the end of World War II caused European countries to lose their power and become unable to hold the countries they colonized.

After the Second World War, two superpowers emerged in the world, the US and the USSR tried to dominate the world. The countries where are out of this scene that emerged after the Second World War and are still in development are named as Third World Countries. The Third World Countries, which seek to propose a new meaning map outside the ideological codes proposed by the US and the USSR, also exert efforts parallel to the developments in the political context in terms of art.

In this study, the cinema language developed by the Third World Countries, which gained independence along with the decolonization process after World War II, was discussed in the special film Xala made by Ousmane Sembene. In this study, which aims to determine the place of Xala in the context of First, Second and Third cinema, one of the qualitative text analyzes is used. At the end of the analysisit is concluded that Xala is a film that is intended to be the third cinema narrative by using some of the possibilities of the second cinema.
\end{abstract}

Key Words: Western, colonialism, World War II, Third Cinema. 


\section{GíRiş}

İnsanlık tarihinde önemli bir yeri olan Coğrafi Keşifler ve Endüstri Devrimi, Batı ülkelerinin tarihsel süreç içerisinde teknik, teknolojik ve bilimsel anlamda ilerlemesini sağlayan önemli olgulardır. Coğrafi keşiflerle birlikte deniz aşırı imparatorluklar kurulmuş, yeni keşfedilen kıtalarla Batı ülkelerinin refah seviyeleri yükselmiştir. Refah seviyeleri yükselen ve gelişen Batı ülkeleri 1800'lü yılların sonlarında dünyanın dörtte üçünden fazlasına egemen duruma gelmişlerdir. Asya ve Afrika Kıtaları'nın büyük bölümleri gelişmelerini sürdüren Batı devletleri tarafından sömürge haline getirilmiştir. İkinci Dünya Savaşı'na kadar sömürgecilik devam etmiş ancak savaş sonunda dengeler değişmiştir. Savaş, Batı Devletlerinin güç kaybetmesine ve sömürgelerini kaybetmelerine neden olmuştur. İkinci Dünya Savaşı'ndan sonra Amerika Birleşik Devletleri dünya egemenliğine yükselmiş ve dünya $S S C B$ ve $A B D$ olarak iki kutba ayrılmıştır. ABD ve SSCB öncülüğünü ettikleri sistemlerini dünya geneline yayabilmek için çaba sarf etmişlerdir. Üçüncü Dünya Ülkeleri ise bu çabanın alanlarından birini oluşturmaktadır. İki kutup dışında kalan diğer dünya ülkeleri ise Üçüncü Dünya Ülkeleri olarak adlandırılmışlardır. Bu devletler henüz sanayileşme aşamasında olan gelişmişlik seviyeleri tamamlanmamış ülkelerden oluşmaktadır. Bağımsızlıklarını yeni kazanmış olan bu ülkeler kendi iç sorunlarını çözmeye çalışmakta sömürüsünden kurtuldukları ülkelerin izlerini silmek, öz değerlerine dönmeye çabalamakta aynı zamanda ilerleme adına iki kutuplu dünyanın sistemlerinden birine dahil olma çabaları görülmektedir.

Buradan hareketle çalışmada öncelikle kolonizasyon ve dekolonizasyon ve neokolonizasyon kavramları Batı özelinde ele alınmış, üçüncü dünya kavramının ortaya çıkmasındaki temel argümanlar irdelenmiş ve Üçüncü Dünya Ülkeleri'nin geçirdiği toplumsal dönüşüm incelenmiştir. 
Sinemanın yalnızca bir estetik yapı değil aynı zamanda toplumsal olay, buhran, sıkıntı ve toplumsal dönüşümlerden etkilenen bir yapıda olduğundan hareketle Muhalif Sinema'nın ortaya çıktığı, beslendiği kaynaklar, etkilendiği diğer akımlar incelenmiştir. Sinemada anlatı kavramı, Birinci, İkinci ve Üçüncü sinemanın anlatı farklılıkları (klasik-politik- modern) ele alınmıştır. Çalışmada genel hatlarıyla dekolonyal süreç sonrasında ortaya çıkan Afrika sineması Sembene'nin Xala anlatısı özelinde, filmlerin üretildikleri tarihsel dönem içinde yer aldıkları bağlamda değerlendirilmesini içeren tarihsel film eleştirisi yöntemiyle çözümlenmiştir.

\section{BATI TARİHI AÇISINDAN ENDÜSTRILLEŞME VE SÖMÜRGECİLIKK}

İnsanlık tarihi açısından önemli bir dönem olan Coğrafi Keşifler boyunca yeni kıtalar keşfedilmiş, dünya denizler yoluyla dolaşılmış ve ticaret dünya ölçeğinde yapılmaya başlanmıştır. Bu gelişmeler ışı̆̆ında yeni kıtaların keşfedilmesi Avrupa'nın gelişmesine ve keşfedilen bölgelerdeki doğal servetlerin kaynak olarak kullanılmasını sağlamıştır (Arnold,1995:3).Rönesans hareketleri bir anlamda Avrupalılık bilincinin ortaya çıkmasını sağlamış ve 16. Yüzyıl ise Coğrafi Keşifler'in hız kazandığı ve sömürgecilik faaliyetlerinin şekillenmeye başladığı bir dönem olmuştur. $\mathrm{Bu}$ dönemde matbaa, barut ve pusulanın kullanılmaya başlanması Avrupalılar lehine önemli üstünlükler sağlamıştır (Evren, 2003: 39).

Bu dönemde Afrika ve Asya'dan getirilen altın, mücevher, ipek, porselen ve baharat gibi ürünler Avrupa'nın dikkatini çekmiştir (Hanilçe,2010:5556).Romalılar döneminden itibaren dünyanın farklı yerlerinden Avrupa'ya gelen mallar Avrupa'nın kendi ürünlerini üretmesiyle gerekliliğini yitirmeye başlamıştır. Fakat altın bunların dışında bir konumda olmuştur. Altın Ortaçağ sonunda Avrupa için lüks bir tüketim maddesi olmakta öte durumdaydı. Avrupa'nın para ve genişleyen ticari sisteminin vazgeçilmez unsurları içerisinde yer almaktaydı (Hanilçe,2010:56-59). Avrupalılar 1800'lü yıllarda dünyanın farklı bölgelerinden gelen kaynaklarla bulunması neredeyse imkânsız olan binlerce 
ürün bulmuşlar bu durum ise toplumun ekonomik, sağlık gibi birtakım ihtiyaçlarını sağlamış ve refah seviyesi giderek artmış bu sayede Avrupa devletleri dünyada üstün konuma gelmeye başlamıştır (Roberts,1996: 438-439). Buradan hareketle 19. Yüzyıl'da tüm dünya ekonomi ve politikasına Avrupa devletlerinin egemen olduğu söylenebilir. Bunu sağlayan ise Avrupa'ya akan hammadde, ürün ve buna bağlı olarak gelişen endüstrileşmedir. Endüstrileşme ve doğa bilimlerinde meydana gelen önemli buluşlar ve bunun sonucunda artan üretimin refah seviyesini yükseltmesi, yeni buluşların üretime uygulanması ve belki de en önemlisi buhar gücüyle çalışan makinenin doğmasıdır. Bu sayede buhar gücüyle çalışan makine, makineleşmiş endüstriyi doğurmuş ve bu da Avrupa'daki sermaye birikimini önemli ölçüde artırmıştır (Sander, 2000: 186-187). Avrupa tarihinde sömürge sahibi olmak büyük devlet olmanın temel şartı olarak görülmektedir (Armaoğlu, 2010: 597).

19. Yüzyıl'ın ortalarında buharlı makinenin bulunmasıyla Sanayi Devrimi'ni gerçekleştiren Avrupalı devletler büyük oranda hammaddeye ihtiyaç duymuşlardır. Kendi ülkelerinin hammadde açısından fakir olması bu devletlerin farklı arayışlara girmesine neden olmuştur. Bu ihtiyaç Avrupalı devletleri hammadde yönünden zengin askeri ve gelişme yönünde fakir Afrika'ya yöneltmiştir. Sömürge konferansı olarak da bilinen 1885 Berlin Konferansı Avrupalıların Afrika kıtasını ticari prensipler doğrultusunda paylaştıkları temel toplantıdır (Demir, 2011:124). Avrupalı devletler kendilerine uygun olan ülkeleri aralarındaki anlaşmalarla bölerek sömürge haline getirmişlerdir.

Endüstrinin gelişmesi, nüfus artışı hammadde kaynaklarına ve mamul eşyaların sürülmesi için pazarlara olan ihtiyaç bunları Avrupa dışına taşıma zorunluluğu getirmiştir. Bu anlamda ilk olarak Fransa' da ortaya çıkan sömürge hareketleri hızlı bir şekilde diğer Avrupa ülkelerine de sıçramıştır (Karal, 1999: 258-259).Sömürge haline getirilen ülkelerden istenilen kaynak ve hammaddenin alınabilmesi ve Avrupa'ya aktarılabilmesi için birtakım araçlara ihtiyaç vardır. Bu anlamda 
sömürülen ülkelerde binlerce kilometre demiryolları inşa edilmiştir. Çünkü 19. ve 20. Yüzyıllar, demiryolu taşımacılığ 1 gerek emniyet gerek kapasite açısından en uygun taşıma sistemidir (Aktaran Demir, 2011: 123). Bu sayede birçok Afrika ülkesi uzun yıllar boyunca Avrupa devletleri tarafından gerek tarım gerek yer altı kaynakları gerekse işgücü anlamında sömürülmüştür.

\subsection{Sömürgeciliğin Temel Araçları: Dil ve Din ve Sanat}

Sömürge sahiplerinin sömürge haline getirmek istedikleri ve sömürgelerini ellerinde tutmak için kullandıkları temel araçlar vardır: dil, din ve sanat. $\mathrm{Bu}$ unsurlar birbiriyle ilişkili olarak kullanılmıştır. Sömürgeci devletler Afrika halklarını kontrol etmek için öncelikle bu halkın formatlarını değiştirmek istemişlerdir. $\mathrm{Bu}$ anlamda kitlede işleme başlamadan dil ve dini etkili olarak kullanmışlardır. Sömürge devletleri misyonerler yoluyla kitlelerin formatını değiştirmeyi başarmışlardır (Demir, 2011:129). Örneğin dil konusunda Belçikalılar Kongo' da ilk olarak yerel kabilelerden üst katmandaki çocukları Fransızca eğitim veren okullara göndermişler ve bu sistem içerisinde eğitim alan çocuklar yerel halk içerisinde üst katmanda olmanın vermiş olduğu gücü kullanarak aldıkları Fransızca eğitim sayesinde Belçikalıların en önemli dil köprülerini kurmuşlar bu ise Fransızcanın prestijli bir dil olarak görülmesini sağlamıştır(Demir,2011:130).Dil konusunda görülen uygulamalar din konusunda da mevcuttur. Dil ve din unsurlarının sömürgecilikte kullanılmaları iç içe ve etkileşimli olmuştur. Batılı misyonerler kitlelerin dinlerini değiştirmelerine ve nüfusun büyük bölümünün Hıristiyan olması için çaba harcamışlardır (Demir, 2011: 132).

\section{2. İkinci Dünya Savaşı Sonrası Durum ve Üçüncü Dünya Terimi}

1900'lü y1llara kadar devam eden sömürgecilik sömürge sahibi ülkelerin ilerlemesini sağlarken diğer yandan sömürülen ülkelerin geriye gitmesine neden olmuştur. Ancak 1900'lü yılların ortalarında dünyada değişen konjonktür ve güç dengeleri farklı bir dünyanın ortaya çıkmasını sağlamıştır. Özellikle İkinci Dünya Savaşından sonra çok farklı bir dünya ortaya çıkmıştır. Dünyanın iki süper gücü 
$A B D$ ve SSCB yeni dünyanın iki aktörü durumuna gelmişlerdir. İkinci Dünya Savaşına kadar dünyanın hâkimi diğer ülkeler güç kaybetmiş bu tarihe kadar ellerinde bulundurdukları hâkim sömürge düzenleri de sürdürülemez hale gelmiştir. Bu dönemde sömürgeciliğe karşı bağımsızlık hareketlerinin yükseldiği ortam oluşturmuştur (Akın,2017: 121-122) ${ }^{1}$.Avrupa ülkeleri savaş nedeniyle zor durumda kalmış ve sömürge ülkelerinden gelen milli bağımsızlık hareketlerine karşı duramamışlar bu durumun sonunda dekolonizasyon dönemi başlamıştır. Dekolonizasyon 1922-1975 yılları arasında Avrupa ülkelerinin sömürgelerinin ayrılması, çözülmesine işaret etmektedir. İlk etkilerinin Birinci Dünya Savaşında görülmeye başladığı ancak İkinci Dünya Savaşı sonrasında karşı konulamayan bir harekete dönüşmüştür. Bu anlamda self-determinasyonunda etkisiyle 1500-1987 yılları arasında 165 ülke bağımsızlığını kazanmıştır (Strang,1991:434-437)². Dekolonizasyon süreciyle verilen bağımsızlık mücadeleleri her sömürge için farklı şekilde gerçekleşmiş olsa da bu mücadeleler arasında önemli sayılabilecek olanları vardır. Örneğin 1961'de Kübalılar CIA destekli Domuzlar Körfezi çıkarmasına başarıyla karşı koymuş, Vietnamlılar karşı konulması imkânsız zorluklara rağmen ABD’nin askeri gücüne karşı başarılı bir direniş göstermişlerdir (Armes,2011:210). Fransa'nın İkinci Dünya Savaşı sonrasındaki durumu Cezayir'de bağımsızlık ve milliyetçilik yanlısı hareketlenmelerin tetikleyicisi olmuştur. 1 Kasım 1954'te altı Fransız'ın öldürülmesiyle başlayan olaylar 1961 'de yapılan referandumla sona ermiş ve De Gaulle birleşiminin gerçekleştirdiği referandumla yüzde 69 evet oyuyla Cezayir'de otonom bir hükümet kurulmuştur (Ataöv, 1975: 152; Uçarol, 1995: 686). Bu süreçte en büyük sömürge sahibi Britanya'nın sahip olduğu

\footnotetext{
${ }^{1}$ Akın F (2017) İkinci Dünya Savaşı Sonrası Yeni Dünya Düzeni ve Türkiye.İş ve HayatDergisihttp://www.sekeris.org.tr/dergi/multimedia/dergi/56_ikinci_dunya savasi sonrasi yeni dunya duzeni_ve turkiye.pdf, erişim tarihi 28.03.2018.
}

2 Strang D (1991) Global Patterns of Decolonization, 1500-1987, International Studies Quarterly, 35, No. 4, 434- 437, www.jstor.org/stable/2600949, Erişim Tarihi: 28.03.2018. 
sömürgeler de ayaklanmışlardır. Bu anlamda ilk meydan okuma İran'da İngiliz petrol hisselerinin İran devletince millileştirilmesiyle gelmiş, ardından 1956 yılında Nasır’ın Süveyş Kanalı projesini millileştirmesi Britanya özelinde kolonizasyonun geri çekilişine neden olan büyük sebeplerden birisi olmuştur (Sayın,2016: 66). Özgürlüklerine kavuşan halklar yıkıntılardan yeni bir düzen doğacağını ve kararsızlık ortamının son bulacağını zannetmekteydiler ancak zaferin kahramanları olan askerlerin şiddet duyguları, gurur ve güvene kavuşma iştahları sonunda iktidarların askerileşmesine ve bunun kurbanlarının da kentleşmiş sınıflar olmasına yol açmıştır (Ferro,2002:563). Bağımsızlıklarını kazanan ülkeler başta ekonomik olmak üzere birçok sorunla karşılaşmışlardır. Sömürge geçmişine sahip devletlerin yeterli birikimi olmadığı için yine başka devletlerin yardımına muhtaç hale gelmişlerdir. Ayrıca devlet yönetiminde görev alacak nitelikli ve tecrübeli yöneticiler bulmak ayrı bir sorun oluşturmaktadır (Sayın,2016:67-68). Bu dönem Afrika, Sovyet- ABD ya da komünist-antikomünist güçler için mücadele alanı olmuştur. Truman doktrinine göre dünyanın artık sömürgecilikle sürdürülemeyeceğini $\mathrm{ABD}$ anlamıştı. $\mathrm{O}$ halde ittifak edeceği ülkeler ile ABD'nin bir şeyler sağlaması gerekmekteydi. Bu doktrine göre açülkeler komünist olmaya mahkumdu, tok ülkeleri belki komünist olmaktan kurtarabiliriz şeklinde özetlenen bir anlayış ortaya konmuştu (Akın,2017: 122).

1989 yılında Berlin Duvarı'nın yıkılmasıyla Varşova Paktı dağılmış, Sovyetler Birliği 15 federe devlete ayrılmıştır (Sayın, 2016:6).Sovyetlerin dağılmasından sonra dünyada tek süper güç haline gelen ABD kendi ideolojisi olan liberalizmin ekonomi politikalarını ve siyasetini, kapitalizm içerisine dahil ederek dünyaya egemen olma yolunda ilerlemiştir (İrge, 2005:76). Bu anlamda sömürgecilik İkinci Dünya Savaşı'ndan sonra büyük oranda sona ermiş olsa da sömürü ortadan kalkmış değildir. Uluslararası şirketlerin düşük gelirli ülkelerde konuşlanmış şubeleri büyük kârlar elde etmeyi sürdürmüşlerdir. Bu anlamda yoksul ülkeler sanayileşebilmek için zengin ülkelerden borç almaya zorlanmış ve böylece 
ekonomik bağımlılıkları artmıştır (Giddens, 2013: 455-456). Sanayisi ve ekonomik gelişimi yavaş ilerleyen ve dünyanın gerisinde kalan Üçüncü Dünya Ülkeleri sanayileşme ve refah seviyesine ulaşabilmek için birtakım önlemler almakta, durumlarını düzeltebilmek için içeriden ve dışarıdan gelen tehditleri yok etmeye çabalamaktadır. Bu anlamda Üçüncü Dünya Ülkeleri ekonomik, siyasi, askeri hatta sanatsal anlamda kendilerine özgü bir dil geliştirmek için uğraşmışlardır. Bu uğraş alanına toplumları ve kitleleri etkileyebilme gücüne sahip sinema da girmektedir.

\section{SINNEMADA ANLATI DIYYALEKTIĞİ: BíRINCI, İKINCİ VE ÜÇÜNCÜ SINEMA}

Anlatı, filmin hikayesi, karakterleri ve konusunun geçmiş olduğu mekanlar üzerine yoğunlaşarak gerçek ve kurgusal olayların iletilmesini içermektedir (Wright, 2006: 19).Bireyin yaşamında önemli bir yeri olan roman, öykü, film, masal ve reklam gibi metinlerin hepsi birer anlatıdır. Barthes (1993:86) anlatının insanlık tarihi ile başladığını ve bütün zaman ve toplumlarda görüldügünü ifade etmektedir. Bordwell ve Thompson (2008:75) anlatının belli bir zaman aralığında neden-sonuç ilişkisine dayalı bir durumla başlayan ve neden-sonuçlara bağlı olarak değişimlerin yaşandığı ve sonuç olarak yeni bir durumu ortaya çıkardığını ileri sürmektedir.

\subsection{Hollywood Tarz1: Birinci Sinema}

Klasik anlatı, Aristoteles'in Poetika adlı eserinde yapmış olduğu gibi Tragedya terimine dayanmaktadır. Poetika' da tragedya tamamlanmış ve bir uzunluğu olan eylemin taklidi olarak tanımlanmıştır (Aktaran Günay,2015: 402). Sinema filmlerinde görülen serim-düğüm-çözüm bölümlerinin çıkış noktası aslında tragedyanın taklitçilik anlayışının bir ürünüdür (Günay, 2015:402).

Geleneksel anlatılı filmlerde olay örgüsü içinde öykü ve aksiyon çizgisini ilerletebilecek unsurlar bulundurmalıdır. $\mathrm{Bu}$ unsurlar çatışma yaratmalıdır 
(Topçu,2004:59). Geleneksel anlatıda olay örgüsü içerisinde bir de karşı güç bulunmaktadır. Bu kahramanın emellerine ulaşmaması için çabalar. Kısaca geleneksel anlatılı filmlerde dramatik yapıda sebep-sonuç ilişkisinin iyi kurulmasılolay örgüsünde boşlukların oluşmamasını sağlar. Buradan hareketle geleneksel anlatılı filmler izleyicinin zihninde sorular oluşmasına izin vermeyen ve izleyiciyi pasif/edilgen hale getiren yapılardır (Topçu, 2004:59).Bu anlamda Hollywood sinemasının klasik anlatılı filmler ortaya çıkarttı̆̆ı söylenebilir. Hollywood sinemasında öykünün gelişim çizgisi şu yöndedir. Önce mekânın durumunun tanımlanması sonra bir sorunun varlığ 1 ve değişimi, önceki ve yeni gelişenin çatışması ilkesel olarak desteklenenin kazanması ve sonuca ulaşılmasıdır (Günay, 2015: 403).Bu tarz sinemacılık aracılığıyla kurulan dünyada iyiler daima kazanırken kötüler en sonunda kaybetmeye mahkumdur. Bu anlamda klasik anlatılı filmlerin tıpkı masallar gibi mutlu sonla bittikleri söylenebilir (İpek, 2017:77).

\subsection{Avrupa Tarzı: İkinci Sinema}

İkinci ya da modern sinema olarak nitelendirilen anlatı tarzı ilk olarak fütürizm ve konstrüktivizm gibi sanat akımlarının sinemaya etkilerinin yanında Dziga Vertov'un sine-göz adlı manifestosu aracılığıyla ortaya çıkmıştır denebilir. Bu anlamda Vertov'un Kameralı Adam filmi klasik anlatı sinemasına ait özelliklerin nasıl ortadan kalktığının belirtileriyle doludur. Filmin ve adı geçen manifestonun ortaya koyduğu sinema anlayışına göre anlatı öykücülükten soyutlanmalı ve yalnıza içinde yaşadığımız dünyanın gerçeklerine odaklanmalıdır(İpek, 2017:7879. Çağdaş anlatılı filmlerde geleneksel anlatının tersine bir başlangıç ya da son yoktur. Filmler çoğu zaman günlük hayattan alınan ve olağan süreçte ilerleyen bir kesitle başlayıp biterler. Olayların başı ve sonu filmde gösterilenlerle sınırlı değildir. İzleyici bunlar hakkında düşünmeye ve yorum yapmaya sevk edilmektedir. Filmin sonunda seyirci kendisini koltuğunda güvende hissedeceği yerde tamamlanmamışlık hissi içerisinde salondan ayrılır. Olayların 
nedenselliğinin zaman ve mekandaki akılcı bir düzenleme ile aktığı geleneksel anlatı sinemasına karşılık çağdaş anlatıda zaman düz bir şekilde akmaz. Zaman mekân sınırlamasından sıyrılmakta şimdinin geçmiş ve gelecekteki iç içe geçtiği bu yeni zaman anlayışı bireyin algıladı̆̆ı öznel bir zamanı göstermektedir. (Bordwell vd,1985: 641).

\subsubsection{Birinci ve İkinci Sinemanın Ayrımlanması}

Karşı sinema karamı ilk olarak 1970'li yıllarda Peter Wollen tarafından kullanılmıştır. Wollen bu kavramla temel olarak geleneksel anlatı sinemasına karşı çıkan, bu anlatı kodları ve kurallarıyla mücadele içerisine giren tarza gönderme yapmıştır denebilir. Karşı sinema kavramı kısaca klasik anlatı sinemasına dair tüm unsurları reddeden bir yapıya sahiptir. (Gürkan, 2015: 24).

Sinemada kullanılan anlatıların ayrımlarının daha net anlaşılabilmesi için Peter Wollen'ın eserlerine uyguladığ 7 maddelik şablon çıkarılmıştır (Wollen, 2012:5).

Tablo 1. Birinci ve İkinci Sinemanın Ayrımlanması

\begin{tabular}{|c|c|}
\hline HOLLYWOOD ANLATISI & KARŞI SINEMA ANLATISI \\
\hline Anlatı Geçişkenliği & Anlatı Geçişsizliği \\
\hline Özdeşleşme & Yabancılaşma \\
\hline Şeffaflık & Ön Plana Çıłkarma \\
\hline Tek Diegesis & Çoklu Diegesis \\
\hline Kapalılık & Açıklık \\
\hline Haz & Rahatsız Olma \\
\hline Kurgu & Gerçeklik \\
\hline
\end{tabular}

(Wollen, 2012: 8)

Wollen, karşı sinemanın yedi ölümcül günahını yapı bozumuna uğrattığını savunmaktadır. Godard ve Karşı Sinema adlı makalesinde bu günahların ve karşı sinemanın oluşturduğu farklılıklar üzerinde duran Wollen öncelikle anlatı geçişkenliği ilkesini ele almaktadır. Buna göre Hollywood sineması imgelerin 
birbirine nedensellik ilişkisiyle bağlı olduğu bir anlatı formu kullanmakta bu form ise birbirine sıkıca bağlı olan olay örgüsünden oluşmaktadır. Karşı sinema ise anlatı geçişsizliğini bunun karşısına koyarak filmik akışı kesintiye uğratmaktadır (Wollen, 2012: 121).

Wollen'ın kıyaslamasına göre geleneksel anlatıda mevcut olan kodlar çağdaş anlatıda tam tersi olarak karşımıza çıkmaktadır. Wollen anlatı geçişkenliği kavramıla her sahnenin kendisinden önceki sahneyi nedensellik zincirine göre takip etmesi durumunu kast etmektedir. Özdeşleşme ise yıldız ya da karakterle olan etkileşimdir. Hollywood anlatısındaki temel düşünce izleyicinin izlediğinin bir film olmasını unutması üzerine kuruludur ancak modern anlatıda ise izlenilenin bütün yönleriyle bir film olduğu vurgulanır. Özellikle teknik unsurların kamera önünde görülmesi izleyicinin izlediğinin bir film olduğunu unutmaması sağlanır (Wollen, 2012: 8).

Hollywood izleyiciyi eğlendirmekte ve onlara iyi vakit geçirme imkânı sağlamaktadır. Modern anlatı ise izleyiciyi rahatsız etmeyi ve işlediği sorunlarla dikkat çekmek ve provoke etmeyi amaçlamaktadır. İzleyicinin klasik anlatı da karakterle özdeşleşmesi için çabalanırken modern anlatıda ise özdeşleşmenin gerçekleşmemesi için çabalanmaktadır (Wollen, 2012: 9).

\subsection{Devrimci Tarz: Üçüncü Sinema}

İkinci Dünya Savaşı sonrasında bağımsızlık mücadelesi veren Üçüncü dünya halkları ve politikacıları kadar film yapımcıları tarafından da durum kişisel ve ulusal bir kimlik duyumu olarak tanıtılmış ve Batılı olmayan dünyanın birçoğunda bireysel yönetmenler yerel eğlence sinemasının geleneklerini bozarak kendilerini ifade etmenin yollarını bulmuşlardır (Armes, 2011:191). Brezilya'da Glauber Rocha, Bolivya'da Jorge Sanjines, Senagal'de Ousmane Sembene gibi birçok sinemacı 1950 kuşağının aksine bu yönetmenlerin ulusal ve uluslararası boyutları olan kolektif bir devrimci dönüşüm hareketine katılmışlardır. Bu yönetmenlerin ortak özellikleri sinemanın politik işlevine duydukları inançtır 
(Armes,2011:210). Üçüncü Sinema teorisi, Hollywood sinemasının seyirciyi pasif hale getirmesinin karşısında, izleyicinin aktif edileceği bir sinema anlayışı üzerine oturtulmuştur. Bu teori bağlamında, üçüncü sinemacılar tarafından Amerika'nın eğlence odaklı sineması ve Avrupa'nın birey odaklı sinemasının zararlı olduğu düşünülmüş ve bunların dişında alternatif oluşturabilecek yeni eğilimler için çaba sarf edilmiştir. Sinemayı toplumsal mücadelenin bir alanı olarak gören Üçüncü sinemacılar diğer iki türü toplumsal mücadeleyi etkisiz hale getirmesinden dolayı eleştirmişlerdir. Bunların yerine devrimci mücadeleye katkı sunan, militan sinemayı savunan yönetmenler, teorileriyle tutarlı çalışmalar ortaya koymuşlardır. Fernando Solanas, Octavio Getino, Julio Garcia Espinosa gibi yönetmenler bu türün başlıca temsilcileridir (Biryıldız ve Erus, 2007:19; Odabaş, 2013:20). Üçüncü dünya sinemasındaki daha önce gerçekleşen çabalar teoriden yoksunken 1960'ların politik sinemacıları teorik anlamda da yeni bir bakış açısı geliştirmişlerdir. Kübalı Julio Garcia Espinosa tarafından yayınlanan For An Imperfect Cinema (Mükemmeliyetten Uzak Bir Sinema İçin) ve Arjantinli Fernando Solanas ile Octavio Getino tarafından yayınlanan Towards A Third Cinema (Üçüncü Sinemaya Doğru) bunun en iyi örneklerindendir (Biryıldız ve Erus, 2007:26).

Üçüncü sinema aynı zamanda bir gerilla sineması da olabilir militan bir sinema da bir kurtuluş sineması da. Şiirsel de olabilir romantik de. Herhangi bir konuyu alıp işleyebilir, belirli bir süresi ve belirlenmiş ortak bir biçimi yoktur. Büyük sinema salonlarında gösterilmesi zorunlu değildir ancak gösterilse de bir sakıncası yoktur (Odabaş, 2013:22).Değişen siyasi koşullar ve Üçüncü Dünya Ülkeleri'nin gelişimleri devrimci bir sinemanın oluşmasına zemin hazırlamıştır. Bu anlamda üçüncü dünya yönetmenleri yapacakları filmler için dünyada gelişimlerine uygun bir akım aramışlar ve İtalyan Yeni Gerçekçiliği ilgilerini çekmiştir.

1950'lerin sonundaki üçüncü dünyalı yönetmenler üzerinde İtalyan Yeni Gerçekçiliği'nin çekiciliğinin iki nedeni vardı: benimsenen üretim biçimi ve yeni gerçekçi yönetmenlerin duruşu. Yeni gerçekçi sinema sınırlı imkanlarla yapılan 
bir sinemaydı be genellikle çekimler filmlerin basılması için ödenecek ücret olmadığından izlenemiyordu. Ancak profesyonellik ve sanatsal nitelikleri sayesinde çağdaşı oldukları sefalet, işsizlik ve yaşlılığın gerekçelerini dünyanın geriye kalanına iletme konusunda başarılı olmuşlardır. Bu açıdan bakıldığında üçüncü dünyalı film yönetmenlerinin durumu İtalyan yeni gerçekçilerin durumuyla paralellik göstermektedir (Biryıldız ve Erus, 2007:23-24). Ancak üçüncü sinemacıların durumu yeni gerçekçi sinemacılarla paralel olsa da farkl1lıklar göstermektedir. Onlar düşmanca bir ortamda sosyal ve politik değişim adına gizli olarak çalışan sinemacılardır. Kültürün anti-kolonizasyonun bir parçası olan programları yıkıcı bir sinema önerir ve yüzünü Che ile örneklenen yeni insana çevirir. $\mathrm{Bu}$ yüzden gerilla mücadelesi imgelerle doludur: film bir fitil kamera tüfek, projektör saniyede 24 kare ateş edebilen bir silahtır. Sinemacı da palasıyla kendine açtığı yolda ilerleyen bir gerillaya benzetilir. Solanas ve Getino için sinemanın anti-kolonizasyonu sinemanın eski algılanış biçimleri ile kolonyalizm ve yeni-kolonyalizmin biçimlendirdiği eski imajı yıkmak ve tüm ifade biçimlerinde doğruyu yeniden yakalayan, yaşayan bir gerçeklik kurmak yani yeni bir sinema yaratmak olarak birbirini tamamlayan iki işlem içermektedir (Solanas ve Getino, 1997).

Aşağıdaki sinema anlatılarını tanımlayan maddeler, uygulama bölümünde örneklem olarak seçilen film üzerinde uygulanacak, ortaya çıkan sonuçlara göre anlatının Birinci, İkinci ya da Üçüncü sinemaya olan yakınlığı bulgular kısmında belirtilecektir. Örneğin anlatı Üçüncü sinema özelliklerinden 5/7 tanesini taşıyorsa anlatı spektrumunda Üçüncü sinemaya daha yakında konumlanacaktır. 
Tablo 2. Birinci, İkinci ve Üçüncü Sinemanın Ayrımlanması

\begin{tabular}{|l|l|l|}
\hline \multicolumn{1}{|c|}{ Üçüncü Sinema } & İkinci Sinema & Birinci Sinema \\
\hline $\begin{array}{l}\text { Mekâna, İnsana ve Toplumsal Olana İlişkin } \\
\text { Yeni Toplu Bakışlar Üreten }\end{array}$ & $\begin{array}{l}\text { Anlatı } \\
\text { Geçişsizliği }\end{array}$ & Anlatı Geçişkenliği \\
\hline $\begin{array}{l}\text { Estetik ve İçerik Olarak Yenilikçi Bir Düzene } \\
\text { Sahip }\end{array}$ & Yabancılaşma & Özdeşleşme \\
\hline $\begin{array}{l}\text { İkili Karşıtlıkları Altüst Edip Var Olan } \\
\text { Parametreleri Yıkan }\end{array}$ & $\begin{array}{l}\text { Ön Plana } \\
\text { Çıkarma }\end{array}$ & Şeffaflık \\
\hline $\begin{array}{l}\text { Estetik Kodlarını Ona Karşı Olmakla Değil, } \\
\text { Kendi Kültürünün Şekillendirdiği Öğelerle } \\
\text { Kurmaya Çalışan }\end{array}$ & Çoklu Diegesis & Tek Diegesis \\
\hline $\begin{array}{l}\text { Asimile Edici Niteliklerine Mukavemet } \\
\text { Gösteren }\end{array}$ & Açılık & Kapalılık \\
\hline $\begin{array}{l}\text { Kapitalist ya da Sosyalist Düzenden Herhangi } \\
\text { Biri Tercih Etmeyen }\end{array}$ & Rahatsız Olma & Haz \\
\hline $\begin{array}{l}\text { Çekilen Filmler Sansüre Uğramış, } \\
\text { Yasaklanmış, Yönetmenleri Sürgün Edilmişya } \\
\text { da Cezalandırılan }\end{array}$ & Gerçeklik & Kurgu \\
\hline
\end{tabular}

Yukarıdaki tabloda Birinci sinema Hollywood tarzı, geleneksel anlatı yapısına sahip filmler, İkinci sinema ise Avrupa tarzı, Avrupa sanat sineması için ve Üçüncü sinema ise devrimci tarzda yapılan gerilla sineması baz alınarak oluşturulmuştur. Sinema anlatılarının Birinci, İkinci ya da Üçüncü olarak nitelendirilebilmesi için yukarıda verilen tablodaki öncüllere uygun olması gerekmektedir.

\section{AMAÇ VE YÖNTEM}

Bu çalışma, İkinci Dünya Savaşı sonrasında dekolonizasyon süreci ile birlikte bağımsızlığını kazanan Üçüncü Dünya Ülkeleri’nin geliştirmiş oldukları sinema dilini, yönetmenliğini Ousmane Sembene' nin yaptığ 1 Xala filmi özelinde ele alarak adı geçen anlatının Birinci/İkinci ve Üçüncü sinema bağlamındaki yerini 
saptamayı amaçlamaktadır. Çalışmada örneklem olarak seçilen film, nitel metin çözümlemeleri içerisinde kullanılan tarihsel film eleştirisi yapılarak analiz edilecektir. Analiz, tarihsel film eleştirisi temel alınarak oluşturulan sorulara bağlı olarak yapılmıştır. Analiz yapılmadan önce tarihsel film eleştirisi hakkında bilgi vermek daha doğru olacaktır.

Tarihsel film eleştirisi filmlerin üretildikleri tarihsel dönem içinde yer aldıkları bağlamda değerlendirilmesini içermektedir. İster güncel bir filmin ister eski tarihler içinde üretilmiş bir filmin eleştirisini yapmak demek, söz konusu filmi tarihsel bir bakış açısı içine yerleştirmek ya da tarihsel bir bakış açısı içinde değerlendirmek demektir (Özden, 2004: 119-120). Bu anlamda tarihsel film eleştirisinin temel işlevi filmleri tarihsel bağlam içinde değerlendirmek üzere, zaman içerisinde meydana gelen değişimleri filmler özelinde incelemek, sinema endüstrisi içindeki uygulama, değişim ve gelişmelerin filmler üzerindeki etkisini çözümlemektir. Diğer yandan tarihsel film eleştirisi filmlerin üretilmiş oldukları dönemlerle ilgili araştırmalar yapmak, filmin içinde yer aldığı tarihsel dönemin sosyal bağlamı ile ilişkisini incelemek, özetle filmleri tarihsel etkileri ve etkilenmeleri çerçevesinde değerlendirmektir (Özden, 2004: 121).

\section{XALA FILMININ TARİHSEL FÍLM ÇÖZÜMLEMESİ VE BULGULAR}

Bu başlık altında Xala filminin tarihsel çözümlemesi yapılacak, anlatının yukarıda verilen tabloda hangi sinema anlatısına uygun olduğu bulgular kısmının sonunda belirtilecektir.

\subsection{Xala Filminin Olay Örgüsü}

Filmin açılış sekansında Fransız sömürgesinden kurtulan Senegal ve devlet adamları beyaz adam ve onların sembolik eşyalarının dışarı çıkarılmasıyla başlamaktadır. Bağımsızlığını kazanmış Senegalli devlet adamları toplantı yapmaktadırlar. Yöneticilerden biri olan El Hadji bağımsızlıklarını kazanmalarını üçüncü eş alarak kutlamaktadır ve diğer devlet yöneticilerini de düğününe davet 
eder. Ancak gerdek gecesi El Hadji cinsel yönden iktidarsız olduğunun farkına varır. İktidarsızlığını gidermek için her türlü yola başvurur. Çeşitli şeyhlere gider, büyü yaptırır fakat ne kadar çabalasa da bu hastalıktan kurtulamaz. İktidarsızlığını gidermek için gittiği yerlere yüklü ödemeler yapar ve aynı zamanda bir tüccar olan yönetici maddi sıkıntılar yaşar. Yerel halka oldukça sert davranan aynı zamanda bir tüccar olan El Hadji iktidarsızlıktan ne yaptıysa kurtulamaz ve iflas eder. Yüklü ödemelerinden dolayı iflas eden El Hadji devlet yöneticiliğinden de kovulur. Aslında El Hadji'a yerel halk büyü yapmıştır ve büyünün bozulması için son sahnede aşağılayıcı şekilde halk tarafından soyularak yüzüne tükürülür.

\subsection{Xala Film Analizi}

Film analizi tarihsel film eleştirisi göz önünde bulundurularak ortaya çıkarın aşağıdaki sorular üzerinden yapılacaktır.

i. Film hangi yıllarda geçiyor ve geçtiği yılları yansıtıyor mu?

ii. Filmin konusu dönemin sosyal yapısına uygun mu?

iii. Başkarakter/lerin cinsiyet, meslek ve sınıfları nelerdir?

iv. Başkarakter/lerin sosyal konumu ve toplumsal statüleri nelerdir?

v. Başkarakter/lerin içinde bulunduğu psikolojik durum nedir?

vi. Film Birinci/ İkinci/ Üçüncü sinema tablosunda belirtilen ölçütlere ne kadar uyum gösteriyor?

\section{i. Film hangi yıllarda geçiyor ve geçtiği yılları yansıtıyor mu?}

Xala filminin filmik zamanı belli olmamasından dolayı filmin zamanı çekildiği yıl kabul edilecektir. 1974 yılında çekilen filmde mekân bilgisi verilmese de anlatıda yapılan göndermeler mekânın Senegal olduğunu göstermektedir. 1970'li yıllar İkinci Dünya Savaşı sonrasında dünyanın iki kutba ayrıldığı, iki büyük gücün çekişmesine sahne olan yıllardır. Afrika açısından ise İkinci Dünya Savaşı sonrasında sömürge sahibi ülkelerin zayıflaması sonucu sömürgelerini ellerinde tutamaz hale geldikleri yıllardır. Buna bağlı olarak 1900'lü yıllardan itibaren 
bağımsızlık çabaları verilmeye başlanmıştır. Özellikle 1922- 1975 yılları dekolonizasyon dönemi olarak karşımıza çıkmaktadır. Sömürgeye karşı çıkış 1900'lü yıllarda özellikle Cezayir bağımsızlık savaşında kendini göstermiştir. İngiltere karşısında 1956 yılında Süveyş Kanalı'nın millileştirilmesiyle devam eden başkaldırı kendini 1955-1975 yılları arasında Vietnam’da göstermiştir. Buradan hareketle filmin çekilmiş olduğu 1974'te dünyanın içinde bulunduğu durum sömürgeleştirmeye karşı çıkan, bağımsızlık mücadelesi vererek kendi yolunu çizmeye çalışan birçok ülke vardır. Bağımsızlığını kazanmış olan ülkeler ise sanayileşme ve gelişme yolunda adımlar atmaya çabalamaktadırlar. Sembene'nin filminde de Senegal bu ülkelerden biri durumundadır. Sonuç olarak film çekildiği dönemdeki temel argümanları yansıtmaktadır.

\section{ii. Filmin konusu dönemin sosyal yapısına uygun mu?}

Xala filminin konusuna bakıldığında bağımsızlığını kazanan Senegal, kendi devlet yönetimini kurar ve gelişme yolunda adımlar atmak ister ancak devlet adamlarının tecrübesiz olması, ellerinde bulunan gücü kendi lehlerine kullanmaları ve halka yeterince ilgi göstermemeleri sonları olmaktadır. Bu anlamda özellikle yeni bağımsız olan ülkeler için 1900'lü yıllar dünyanın iki kutuplu olduğu, bunların dışında kalanların ise Üçüncü Dünya Ülkeleri olarak adlandırıldığı bir dünyadır. Yeni bağımsız olan ülkeler ya iki kutuptan birini tercih edecek ya da gelişebilmek için kendi yolunda uzun ve meşakkatli bir yol izleyecektir. Sembene'nin filminde yöneticiler Batı'yı örnek almaktadır. Kullandıkları araçlar, içtikleri su, günlük konuşma dillerine kadar tüm yaşam pratikleri modern Batı üzerine kuruludur. Ayrıca bağımsızlığını ilan eden ülkelerin yöneticileri asker ya da devlet adamı farkı oluşturmaksızın ellerinde bulundurdukları gücü toplumun yararından ziyade zararı için kullanmışlardır. Xala filmi içinde benzer durumdan söz edilebilir. El Hadji kendisini görmek isteyen halkı geri çevirir, onlara kötü davranır ya da evinin önünde toplanan kalabalığ1 polis zoruyla dağıtır. Buradan hareketle filmin konusunun geçtiği dönemin koşullarıyla benzerlik gösterdiği söylenebilir. 


\section{iii. Başkarakter/lerin cinsiyet, meslek ve sınıfları nelerdir?}

Xala filminin başrol oyuncusu El Hadji'dır. El Hadji ortalama 40-50 yaşları arasında bir erkektir. Devlet yöneticiliğinin yanında iş adamı ve esnaflık mesleklerini yapmaktadır. Toplumsal statü açısından bakıldığında ulusal burjuvazi olduğu görülmektedir. Fanon (1994:151-152)kitabında sömürge sonunda iktidara gelen burjuvazinin az gelişmiş burjuvazi olduğunu, ekonomik gücünün neredeyse hiç olmadığından bahsetmektedir. $\mathrm{Bu}$ anlamda ulusal burjuvazinin narsizmi, metropol burjuvazisinin ayağını kaydırıp yerini almayı planlamaktadır. Ulusal burjuvazide ne maliyeci ne de sanayici bulunmaz. Tüm enerjileri aracılık faaliyetlerine yönelmiştir. En çok ilgilendikleri şey yolsuzluk yapmak ya da ticari ağlar kurmaktır.

\section{iv. Başkarakter/lerin sosyal konumu ve toplumsal statüleri nelerdir?}

El Hadji fakir ve yeni bağımsızlığına kavuşmuş bir ülkenin bakanlarından birisidir. Yerel halktan farklı bir durumda devletin imkanlarına sahiptir. El Hadjiı'ın sosyal konumu açısından bakıldığında ekonomik anlamda toplumun ilerisinde olduğu söylenebilir. Halk fakir ve sefalet içerisinde yaşamını sürdürürken başkarakter üçüncü evliliğini görkemli bir düğün ile yapmaktadır.

\section{v. Başkarakter/lerin içinde bulunduğu psikolojik durum nedir?}

El Hadji ve diğer yöneticileri ülke yönetiminde tecrübesizdirler. Devletin imkanlarının ve gücünün ellerinde olması yöneticilerin rehavete kapılmalarına neden olmuştur. Bu anlamda yöneticiler aslında halk ve halkın geleceği, ülkenin gelişmesi için çalışmaları gerekirken kendi lüks hayatları ve gelecekleri için çalışmaktadırlar. Yöneticilerin kullandıkları araçlar, içtikleri su, kullandıkları dil gibi hayatın neredeyse tüm pratikleri öz değerlerinden bağımsızdır. Batı ya da modernist bir anlayışla gerçekleştirilen bu yenilikler bir anlamda Batılı beyaz adam gibi görünerek onların ulaştıkları seviyeye gelme girişimi olarak yorumlanabilir. Aynı zamanda El Hadji üçüncü evliliğinde xala (cinsel yönden) 
iktidarsız olduğunu anladığında bu hastalığın üstesinden gelmek için elinden gelen her şeyi yapar. Bunalıma girer, çeşitli büyücü ve şeyhlere giderek bu hastalıktan kurtulma yollarını arar. Hastalıktan kurtulmak için öylesine çabalar ki gittiği yerlerde yaptığı ödemeler mali yönden krize girmesine neden olur. El Hadj ve diğer yöneticiler filmde ülkenin gelişmesine katkı sağlayacak herhangi bir girişimde bulunmazlar aksine, ithal araçlar ile gezerler, ticari ağlar oluşturarak daha fazla para kazanma yolları ararlar.

\section{vi. Film Birinci/ İkinci/ Üçüncü sinema tablosunda belirtilen ölçütlere ne kadar uyum gösteriyor?}

Anlatının temelde eleştirdiği nokta bağımsızlığını yeni kazanmış bir ülkenin yöneticilerinin öz değerleri ile kalkınmaya çabalaması yerine Batı odaklı bir kalkınma yöntemi benimsemesidir. İkinci Dünya Savaşı sonrasında dekolonizasyon süreciyle birlikte bağımsızlıklarını kazanan ülkelerin, dünyanın iki kutbundan herhangi birine dahil olması modern sömürgeciliğin devamı anlamına geldiği yukarıda belirtilmiştir. Buradan hareketle yerel kıyafetli Senegalli yöneticilerin filmin başında beyaz adamı ticaret odasından çıkarıp bağımsızlıklarını simgesel olarak kazanmaları sonrasında ticaret odasından beyaz adamın giydiği kıyafetlerle çıkmaları bir anlamda pratikte değişiklik olmadığının göstergesidir. Nitekim anlatının devamında Batılı beyaz adamın kıyafetlerini giyen Senegalli yöneticiler yine beyaz adamın ülkesinden gelen ithal lüks araçlara binmektedirler. Modernleşme ya da Batı'ya öykünme çabaları olarak görülen bu çabalar Sembene tarafından eleştirilmektedir. Diğer yandan filmde kullanılan dilin Senegal'in yerli dili olan Volofça değil Fransızca olduğu görülmektedir. Başkarakterin kızı babasıyla konuşmaya geldiğinde kendisine ikram edilen suyun bile Batı'dan ithal edilmiş olması sömürgenin sona ermediğini yalnızca kabuk değiştirdiğini göstermektedir. El Hadji’ın kızı babasıyla konuşmaya gittiğinde Fransızca konuşmayı reddederek Volofça konuşmak istemiş ancak babası bu duruma şiddetle karşı çıkmıştır. İlerlemenin ve gelişmenin temel koşulunun 
Batı'ya benzemek olduğu başkarakter tarafından kızına iletilmiştir. Düğün sahnesinin girişinde yerli burjuvazi Batı'dan ithal edilen araçlardan inerek yanlarından hiç ayrılmadıkları para dolu çantalarla kalabalığa karışmakta, düğüne davetli olmayanlar girememektedir. Yerel halk yalnızca düğünü izlemekle yetinmektedir. Yönetici elit halkı hiçbir zaman yanlarında istememekte her fırsatta polis zoruyla kalabalıkları dağıtma emri vermektedirler. Düğünde gösterişli giyinen davetliler, verilen kokteyller tam anlamıyla yerel burjuvazinin beyaz adam gibi olma istediğidir. Ayrıca Senegalli yöneticiler ulusal kaynaklardan elde ettikleri paraları Avrupa bankalarına yatırmaktan çekinmemektedirler. Anlatının sonunda El Hadji'ın yerine geçen sokak hırsızının yerel burjuvaziye dahil olması bir anlamda yaşanan bozukluğun gözler önüne serilmesidir.

Anlatı boyunca yerli yöneticilerin yanında yöneten- yönlendiren konumda olan beyaz adamın görülmesi bir anlamda sömürünün devam ettiğinin göstergesidir. Film boyunca xala hastalığından kurtulmak için çabalayan El Hadji'ın hastalıktan kurtulmak için kendisine büyü yapan halkın önüne çıkması ve soyunarak halkın aşağılamasına maruz kalması Sembene'nin sokaktaki öfkeyi simgeleştirmesi açısından önemlidir. Bağımsızlığını yeni kazanan ülkelerin işgal sömürgeciliğinden kurtularak yeni bir sömürge biçimi olan neokolonyalizmesömürgesine evrildiği filmin temel anlatısını oluşturmaktadır. $\mathrm{Bu}$ anlamda anlatının alt metninde modern sömürgeciliğe karşı bir eleştiri vardır. Ayrıca bağımsızlık sonrası dünyada ortaya çıkan süper güçlere tabi olma durumu da Sembene tarafından sert şekilde eleştirilmiştir. Anlatıda yerel burjuvazi eleştirilirken, öz değerler, yerel kültür, yerel dilin kullanılması olumlanmıştır. İzleyici filmi izlerken, amaçları yalnızca kendilerini düşünmek olan, lüks içerisinde yaşayan, halkının ve ülkesinin gelişmesiyle ilgisi olmayan yönetici elitlerine eleştirel gözle bakmaktadır. Ayrıca film Dakar'da gösterime izin verilmeden 11 ayrı planda girdiğisansüre uğramıştır (Armes, 2011:515).Yukarıdaki bilgilerden hareketle anlatı Birinci, İkinci ve Üçüncü 
sinemanın ayrımlanması tablosunda belirtilen estetik kodlarını ona karşı olmakla değil kendi kültürünün şekillendirdiği öğelerle kurmaya çalışan, asimile edici niteliklerine mukavemet gösteren, kapitalist ya da sosyalist düzenden herhangi biri tercih etmeyen, çekilen filmler sansüre uğramış, yasaklanmış, yönetmenleri sürgün edilmiş ya da cezalandırılan kriterleriyle uyum göstermektedir.

Anlatı Hollywood tarzı anlatım biçimi içermemekte, olaylar sıkı bir neden-sonuç ilişkisi içerisinde verilmemektedir. Hollywood anlatılarında karşılaşılan gerçeğin yeniden üretimi yerine gerçekçi bir bakış açısıyla ele alınmakta anlatının alt metninde modernlik ve modern sömürgeciliğe, batılılaşmaya eleştiri bulunmaktadır. Birinci sinemanın temel amacı izleyiciyi pasif hale getirerek istenileni verme, izleyiciye izlediğinin film değil gerçek yaşamdan bir kesitmiş gibi göstererek özdeşleşme sayesinde edilgen bir seyirci elde etmektir. Sıkı bir nedensonuç ilişkisine bağlı olarak gerçekleşen olaylar incelediğimiz film için geçerli değildir. Yer ve zamanın tam olarak belli olmadığı bağımsızlığını yeni kazanmış bir ülke resmedilmektedir. El Hadji'ın neden üçüncü bir kadınla evlendiği ya da sokak hırsızının neden devlet yönetimine girdiği belli değildir. Bu durum Wollen'ın anlatı geçişsizliği kavramıyla ilintili olduğu söylenebilir. Xala filminin sonuna bakıldığında El Hadji’ın aşağılanması haricinde bir sonuç yoktur. Ülkenin durumunun ne olacağı, yönetimin nasıl işleyeceği gibi sorular izleyicinin kafasında soru işareti olarak kalmaktadır. Bu durum ise Wollen'ın kapalılık karşısında açıklık kavramıyla ilişkilendirilebilir. Son olarak haz karşısında rahatsız olma maddesi açısından Xala filmine bakıldığında Sembene'nin olayları çarpıcı ve rahatsız edici şekilde vermesi izleyicinin filmin sonunda etkili bir sonla karşılaşmasını sağlamaktadır. Devlet yönetiminde olan fakat yeni bağımsız olmuş bir ülkeyi kalkındırmaktan ziyade imkanlarından faydalanan ve halkına değer vermeyen bir yönetici halk tarafından yapılan büyüyle cinsel iktidarsızlığa yakalanmış ve büyünün bozulması için El Hadji'ın soyunup halkın önüne çıkması gerekmektedir. Halk El Hadji'ı aşağılar ve yüzüne tükürürler. Bu son, izleyicinin 
filmden haz almaktan ziyade rahatsız olmasına neden olmaktadır. Sonuç olarak Birinci, İkinci ve Üçüncü sinemanın ayrımlanması tablosunda Xala filmi İkinci sinema maddelerinden dört tanesi ile uyum göstermiştir.

Tablo 3. Anlatı Spektrumu ${ }^{3}$

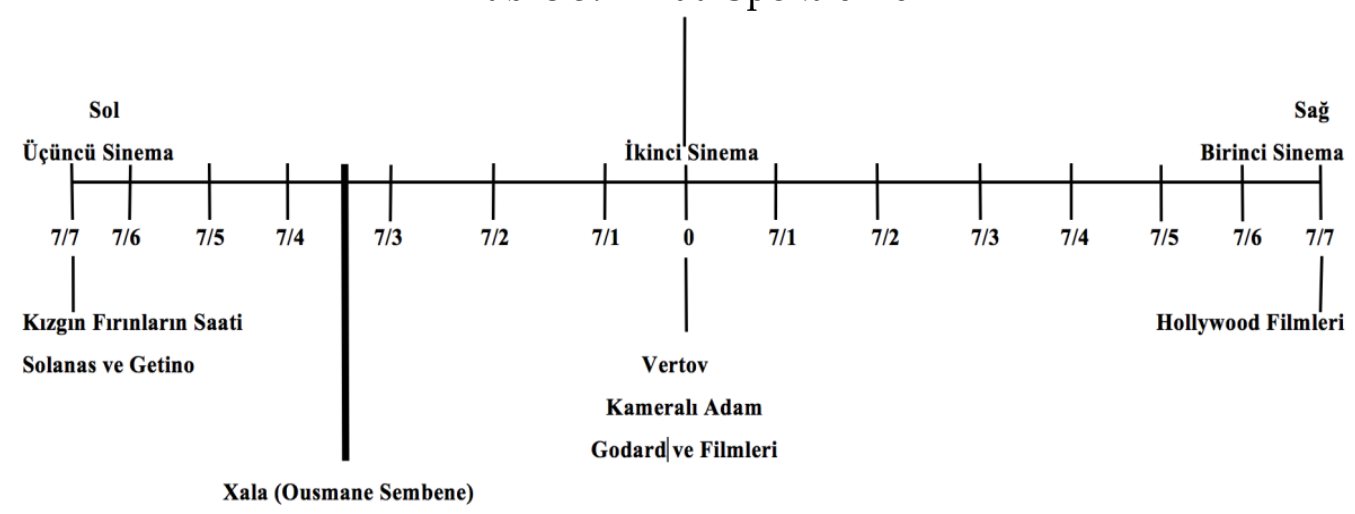

Yukarıda anlatının spektrum üzerindeki konumu verilmiştir. Tablo üzerinden bakıldığında Xala filmi İkinci ve Üçüncü sinemanın temel argümanlarından bazıları ile uyum göstermekte Birinci sinema ile herhangi bir bağı bulunmamaktadir.

\section{SONUÇ YERINE}

Xala filmi siyah Afrika'yı konu alan bir filmdir. Film, Batı ülkelerinin sömürge haline getirdiği ülkelerin bağımsızlıklarını kazandıktan sonra sanayileşme ve gelişme adına ne gibi aşamalardan geçtiklerini gözler önüne sermektedir. Bu anlamda sömürgecilik sonrası bağımsızlığını kazanan ülkeler için kapitalizm gibi modern sömürgecilik biçimleri ortaya çıkmıştır. Ülkelerin bağımsız oldukları yıllarda dünyada süper güç haline gelen sistemlerden birine dahil olma çabaları modern sömürgeciliği ortaya çıkarmaktadır. Xala filminde Sembene, yöneticileri Batı odaklı, modern olmaya çabalayan, ülkelerinin gelişmesi ve ilerlemesi için

\footnotetext{
3 Anlatı Spektrumu oluşturulurken Gülseren Güçhan'ın Tür Sineması, Görüntü ve İdeoloji adlı kitabının 193. sayfasında kullanılan İdeolojik Spektrumdan esinlenilmiştir.
} 
gayret göstermeyen kişiler olarak temsil etmiş, sömürgecilik, emperyalizm, modern sömürgecilik gibi tahakküm altına alıcı bütün olguları bütünüyle reddetmiştir. Yönetici elitin devlet yönetiminde uyguladığı politikaları ve yaşam şekillerini bazen komik, bazen ise sert şekilde eleştirmiştir. Yönetmenin asıl söylemek istediği bağımsızlığını kazanan ülkelerin aslında sömürülmeye devam ettiğini pratikte sadece sömürü biçiminin değiştiğini, bu değişimin ise yeni bağımsız olan ülkenin devlet adamlarınca gönüllü olarak yapıldığıdır.

Sonuç olarak Xala filmi yukarıda belirtilen kriterler (Birinci, İkinci ve Üçüncü sinemanın ayrımlanması tablosu)çerçevesinde değerlendirilmiş, İkinci ve Üçüncü sinema maddelerinden dört tanesi ile uyum göstermiştir. Dolayısıyla film anlatı spektrumunda İkinci ve Üçüncü sinema doğrusu üzerine konumlanmıştır. Sonuç olarak Xala filmi için, İkinci sinemanın olanaklarının bir kısmını kullanan Üçüncü sinema anlatısı olmaya aday bir filmdir denebilir.

\section{KAYNAKLAR}

Armaoğlu F (2010) 19. Yüzyıl Siyasi Tarihi, Alkım Yayınevi, İstanbul.

Armes R (2011) Üçüncü Dünya Sineması ve Batı, Doruk Sinema Yayınları, İstanbul.

Arnold D (1995). Coğrafi Keşifler Tarihi, Alan Yayıncılık, İstanbul.

Ataöv T (1975) Afrika Ulusal Kurtuluş Mücadeleleri, A.Ü. S.B.F Yayınları, Ankara.

Barthes R (1993). Göstergebilimsel Serüven, Yapı Kredi Yayınları, İstanbul.

Biryıldız E Erus Z Ç (2007) Üçüncü Sinema ve Üçüncü Dünya Sineması, Es Yayınları, İstanbul.

Bordwell D Thompson K. Staiger J (1985) The Classical Hollywood Cinema Film Style and Mode of Production, Columbia University Press, New York.

Bordwell D Thompson K (2008) Film Sanatı, De Ki Yayınları, İstanbul. 
Demir A (2011)Sömürge Devletlerinin Kullandığı Sömürgecilik Araç ve Metotları Vaka Analizi: Belçika Krallığının Kongo'daki Sömürge Dönemi, Güvenlik Stratejileri Dergisi, 7, 14, 117-141.

Evren G (2003) Genel Olarak Sömürgecilik Hareketleri ve Antiller Denizi, Pasifik ve Hint Okyanuslarındaki Fransız Sömürgeleri, Sömürgecilik Hareketlerinde Fransa ve Anadolu'da Fransız-Ermeni İşbirliği Bildiri Kitabı, Fırat Üniversitesi Yayınları, Elazı̆̆.

Fanon F (1994) Yer Yüzünün Lanetlileri, Versus Yayınları, İstanbul.

Ferro M (2002) Fetihlerden Bağımsızlık Hareketlerine Sömürgecilik Tarihi, İmge Kitabevi, Ankara.

Giddens A (2013)Sosyoloji, Kırmızı Yayınları, İstanbul.

Güçhan G (1999) Tür Sineması, Görüntü ve İdeoloji, Anadolu Üniversitesi Yayınları, Eskişehir.

Günay Ö M (2015) Geleneksel Anlatı ve Modern Sinema Anlatısı: The Mummy (Mumya) ve Amour (Aşk) Filmlerinin Dramaturjik Çözümlemeleri, Kocaeli Üniversitesi Sosyal Bilimler Kongresi Kongre Kitab1, S. 399-408.

Gürkan H (2015) Karşı Sinema, Es Yayınları, İstanbul.

Hanilçe M (2010) Coğrafi Keşiflerin Nedenlerine Yeniden Bakmak, Tarih Okulu, 7,47-70.

İpek Ö (2017) Peter Wollen' in Karşı Sinema Kavramı, Maltepe Üniversitesi İletişim Fakültesi Dergisi, 4(2) 72-87.

İrge N (2005) Gelişmiş Kapitalizm Eşliğinde Yeni Sömürgecilik, Trakya Üniversitesi. Sosyal Bilimler Dergisi, 6, 1, 59-88.

Karal E Z (1999) Osmanlı Tarihi, IX. Cilt İkinci Meşrutiyet ve Birinci Dünya Savaşı (1908-1918), Türk Tarih Kurumu Basımevi, Ankara.

Odabaş B (2013) Üçüncü Sinema, Agora Kitaplığı, İstanbul. 
Özden Z (2004) Film Eleştirisi Film Eleştirisinde Temel Yaklaşımlar ve Tür Filmi Eleştirisi, İmge Kitabevi, Ankara.

Roberts J M (1996) Avrupa Tarihi, İnkılap Yayınları, İstanbul.

Sander O (2000) Siyasi Tarih İlkçağlardan 1918'e, İmge Kitabevi, Ankara.

Sayın Y (2016) Arap Baharı ve Sömürgelerin Çözülmesi, KMÜ Sosyal ve Ekonomik Araştırmalar Dergisi 18 (30), 65 - 70.

Solanas F Getino O (1997)Alternatif Modernleşme ve Sinema. Yüksek Lisans Tezi

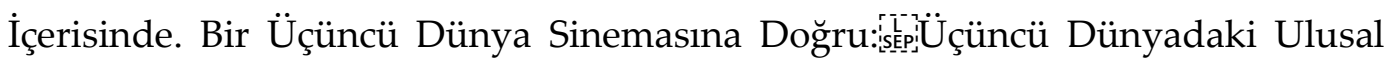
Kurtuluş Mücadelelerinin Bir Parçası Olan Sinemanın Gelişimi Üzerine Notlar ve Deneyimler. ek-2. 138.

Topçu A (2004) Sinema ve Zaman: Geleneksel Anlatı ve Çağdaş Anlatı Filmlerinde Zamanın Kullanımı ve Anlatısal Yapı ile İlişkileri, Vadi Yayınları, Ankara.

Uçarol R (1995) Siyasi Tarih (1789-1994), Filiz Kitabevi, İstanbul.

Wollen P (2012) Godard ve Karşı Sinema, İstanbul Arel Üniversitesi İletişim Fakültesi İletişim Çalışmaları Dergisi içinde, çev. Hasan Gürkan.

Wright M (2006) Religion and film: an introduction, I. B. Tauris And Company Limited, London. 